\title{
TOŻSAMOŚĆ ORMIAN W GALICJI
}

\author{
Krzysztof Stopka \\ Uniwersytet Jagielloński w Krakowie
}

\section{ABSTRACT \\ IDENTITY OF ARMENIANS IN GALICIA}

The Armenians living in Galicia formed an ethnic identity which consisted of a few thousand members, distinguished by the liturgical rite, historical tradition and close family and social relationships. The earliest waves of migration arrived at Lwów and Kamieniec Podolski from the Tatar lands, speaking the Kipchak dialect of the Turkic language group. That ethnolect fell into disuse in the 1660s. The more recent migration groups which came to Poland on the turn of the $16^{\text {th }}$ and $17^{\text {th }}$ century, especially those which arrived in the beginning of the $17^{\text {th }}$ century, spoke various dialects of the modern Armenian language. The usage of this language, however, began to fade on the turn of the $18^{\text {th }}$ and $19^{\text {th }}$ century. The Armenian community was dwindling away without further waves of migration. In this situation, the Armenians were undergoing a linguistic Polonisation and, on a lesser scale, Ruthenisation. They quickly assimilated with the Polish community, belonging to the highest social strata such as the intelligentsia and land owners. During the Spring of Nations, the relationship between Polish and Armenian identity was widely discussed. The most frequent opinion held the Armenian people to be a "tribe" of the Polish nation. The 1860s saw a journalistic dispute on the group's identity. The anonymous author of Głos do ziomków obrzadku ormiańskokatolickiego (Call to fellow followers of the Armenian Catholic rite) made a call to abandon the separate rite and unite with the Poles as one nation. Answering this, Izaak Isakowicz (the future Armenian archbishop of Lwów) fervently defended the Armenian rite and traditions. He did not hold the notion that they were a cause of division among the Polish nation, because the Armenians living in Galicia identified with the Polish reason of state and the Armenian culture enriched the Polish culture. In the 1880s, the Armenian land owner Robert Rosco-Bogdanowicz called his fellow Armenians to defy Polonisation, restore the Armenian language, migrate to the Russian Armenia and propagate Western culture, including Catholicism, in that country. Although the Galician Armenians leaned towards assimilation into Polish culture, the disputes on identity led to the rebirth of the Armenian rite and many initiatives to revive the withering ethnicity. A major role in this process was played by Józef Teodorowicz, the last Armenian-Catholic archbishop of Lwów, who equally identified with Polish and Armenian culture. A popular motto among the Galician Armenians was that "an Armenian is a double Pole."

Key words: Galicia, Armenians, national identity.

Słowa kluczowe: Galicja, Ormianie, tożsamość narodowa. 
Ormianie w Galicji stanowili niewielką wspólnotę etniczną wyróżniającą się głównie obrządkiem liturgicznym, pamięcią historyczną i ścisłymi więziami krewniaczymi (endogamią) ${ }^{1}$. Szacuje się, że w latach 1782-1783 w samej Galicji (bez Bukowiny) mieszkało 2685 osób obrządku ormiańskokatolickiego ${ }^{2}$. Liczba Ormian galicyjskich powinna być jednak powiększona o Ormian katolików na Bukowinie, którzy w większości pochodzili z Galicji i pod względem religijnym, ekonomicznym oraz tożsamościowym byli związani z życiem grupy galicyjskiej ${ }^{3}$. Catalogus universi cleri archi-dioecesis leopoliensis ritus armeni za rok 1843 podawał, że w parafiach galicyjskich było 3060 wiernych (i 4 niekatolików), a na Bukowinie 2155 (w tym 1228 niekatolików), w sumie zatem 5219 osób ${ }^{4}$. Konskrypcja państwowa z 1857 roku wykazała dla samej już tylko Galicji ponad 2407 Ormian, z tego 2309 katolików5 Ogólnie rzecz biorąc, liczbę Ormian w Galicji w pierwszej połowie XIX wieku szacuje się w granicach między 3269 a 3483. Demograficznie liczba ta miała tendencję spadkową. Statystyki państwowe z 1910 roku wykazywały w Galicji 1467 Ormian, zaś kościelne z 1918 roku -2681 wiernych ${ }^{6}$. Najliczniejsza była parafia w Kutach w latach 90. XVIII wieku należało do niej 396 osób, a w roku $1843-1351$.

Rozsiedlenie Ormian w Galicji tuż po 1772 roku do pewnego stopnia pokrywało się z siecią parafii ormiańskokatolickich. Mieszkali oni wyłącznie w Galicji

1 To znaczy, że małżeństwa zawierano w ścisłym kręgu ormiańskim, a liczba małżeństw międzyobrządkowych była stosunkowo niewielka. O tożsamości Ormian w okresie przedrozbiorowym zob. K. Stopka, Ormianie w Polsce dawnej i dzisiejszej, Kraków 2000, s. 77-88; idem, Ormianie polscy czy ukraińscy? O sposobie pisania historii Ormian na ziemiach dzisiejszej Zachodniej Ukrainy, „Lehahayer” 2010, nr 1, s. 149-171; idem, Ormiańskie sacrum i profanum, czyli o fundamencie kulturowym Ormian polskich [w:] Ormianie, red. B. Machul-Telus, Warszawa 2014, s. 77-98; A.A. Zięba, Patriotyzmy polskich Ormian [w:] Ormianie, s. 45-56.

2 Najbardziej charakterystyczną cechą obrządku, oprócz języka, był zwyczaj udzielania sakramentu chrztu łącznie z bierzmowaniem i nadawania przy tej okazji podwójnych imion - jednego przy chrzcie i drugiego przy bierzmowaniu. Nazwiska ormiańskie miały charakter odimienny. Pochodzily z reguły od imienia ojca (patronimik) lub wspólnego przodka. Do imienia dodawano końcówki słowiańskie -owicz, -ewicz, które w ormiańskich inskrypcjach nagrobnych zastępowane były przez -ianc lub -jenc. W nowożytnym języku ormiańskim formy grabarowe (staroormiańskie) zostały zastąpione przez -ian. K. Stopka, Ormianie w Polsce dawnej i dzisiejszej, s. 25.

3 Bukowina do 1849 r. wchodziła w skład Galicji.

4 Parafia w Czerniowcach liczyła 634 wiernych, a stacja misyjna w Suczawie - 293. Ormian niekatolików było tam odpowiednio 22 i 1206. Czterech Ormian niekatolików wykazywano też w parafii w Śniatynie. Zaledwie rok wcześniej ukazało się opracowanie ks. Franciszka Ksawerego Zachariasiewicza (X.Z. [F.K. Zachariasiewicz], Wiadomość o Ormianach w Polszcze, Lwów 1842, s. 80-81), w którym podawał on nieco inne liczby: dla Galicji 2283 Ormian, dla Bukowiny - 4245 (z czego 1598 nieunitów), czyli w sumie 6528 osób.

5 Pochodzący z 1858 r. katalog duchowieństwa ormiańskiego podawał dla Galicji (bez Czerniowiec i Suczawy) liczbę 3378 wiernych. Catalogus universi cleri archi-dioecesis leopoliensis ritus armeni pro anno 1858, Leopoli 1858.

6 K. Stopka, Ormianie w Galicji austriackiej [w:] Ormiański pasterz Lwowa ksiadz arcybiskup Józef Teodorowicz na tle dziejów ormiańskich, red. W. Osadczy, M. Kalinowski, M. Jacov, Lublin-Lwów 2015, s. 74-77; F. Wasyl, Ormianie w przedautonomicznej Galicji. Studium demograficzno-historyczne, Kraków 2015, s. 60-65. 
Wschodniej. Największe ich skupiska znajdowały się w okolicach Horodenki, Śniatyna i Kut, w powiatach przylegających do Bukowiny.

Najważniejszą instytucją religijną i narodową dla Ormian był Kościół ormiańskokatolicki. Władze austriackie w latach 1784-1786 zlikwidowały bowiem samorząd ormiański z czasów polskich. Na czele archidiecezji ormiańskiej stał arcybiskup rezydujący we Lwowie, podległy bezpośrednio Stolicy Apostolskiej, mianowany przez cesarza spośród trzech kandydatów wybranych wcześniej przez kler diecezjalny ${ }^{7}$. Chociaż duchowieństwo ormiańskie zostało zrównane w prawach z łacińskim, władze austriackie zamykały parafie z niewielką liczbą wiernych, niemające funduszy na remonty kościołów. W 1787 roku przyznano ormiańskiemu duchowieństwu 14 etatów, a ich liczba wzrosła do 27 dopiero w 1855 roku $^{8}$. Kapituła katedralna na wzór łaciński została formalnie powołana w 1803 roku. Jej prepozyt pełnił obowiązki proboszcza parafii lwowskiej. W połowie XIX wieku działało w Galicji tylko osiem parafii podzielonych na dwa, a następnie trzy dekanaty ${ }^{9}$. Ormianie, kandydaci do stanu duchownego, dla których nie było miejsca w rodzimym Kościele, przechodzili głównie na obrządek łaciński ${ }^{10}$. W 1784 roku Ormianie przyjęli kalendarz gregoriański. Po likwidacji seminarium prowadzonego przez zakon teatynów (1784) kler ormiański kształcił się w seminarium łacińskim we Lwowie. Nauka języka liturgicznego (starożytnego grabaru z V w.) i obrządku odbywała się w katedrze i kościołach tego rytu. We Lwowie istniał ponadto klasztor Benedyktynek ormiańskich, a od 1792 roku bank diecezjalny - Mons Pius ${ }^{11}$.

W czasach reform józefińskich zlikwidowano szkółki działające przy kościołach ormiańskich. W zaprowadzonych jednolitych szkołach ludowych nie nauczano języka ormiańskiego, gdyż nie został on uznany za język krajowy. W tej sytuacji język ormiański używany w formie dialektalnej, głównie na Pokuciu, powoli zanikał. Najdłużej przetrwał w Kutach, miasteczku na pograniczu galicyjsko-bukowińskim ${ }^{12}$. Szkoła

7 Stolica Apostolska mianowała kandydata wyznaczonego przez cesarza. Nazywało się to prekonizacją. B. Kumor, Obsada arcybiskupstwa ormiańskokatolickiego we Lwowie w latach niewoli narodowej (1772-1918), „Analecta Cracoviensia” 1994, t. 26, s. 371-385.

8 W 1764 r. we wszystkich parafiach ormiańskich w Polsce pracowało 45 księży.

9 Catalogus universi cleri archi-dioecesis leopoliensis ritus armeni z 1843 r. wykazywał tylko dwa dekanaty: lwowski i kucki, natomiast z 1845 r. - już trzy: lwowski (Lwów), stanisławowski i kucki. Do dekanatu kuckiego należeli Ormianie katolicy w Kutach, Horodence, Śniatynie, Czerniowcach i Suczawie. Do dekanatu stanisławowskiego włączone zostały parafie w Stanisławowie, Brzeżanach, Tyśmienicy i Łyścu.

10 B. Rok, Ormianie w kościele rzymskokatolickim w XVIII wieku [w:] Rola mniejszości narodowych w kulturze i oświacie polskiej w latach 1700-1939, red. A. Bilewicz, S. Walasek, Wrocław 1998, s. $19-41$.

11 Cz. Lechicki, Kościót ormiański w Polsce, Lwów 1928, s. 103-143; G. Petrowicz, La Chiesa Armena in Polonia e nei paesi limitrofi, parte 3: 1686-1954, Roma 1988, s. 215-369.

12 Ormianie lwowscy i kamienieccy, których przodkowie przybywali od średniowiecza z ziem tatarskich (głównie z Krymu), nie znali tego języka w ogóle. Ich rodzimą mową był dialekt kipczacki należący do turkijskiej grupy językowej. Sami nazywali go językiem tatarskim. W latach 60. XVII w. wychodził już jednak z użycia. Po zdobyciu Kamieńca Podolskiego przez Turków w 1672 r. i likwidacji tamtejszej kipczackojęzycznej gminy zanikł niemal zupełnie (przynajmniej w formie urzędowej). Ormianie lwowscy, a później kamienieccy (gmina została odtworzona po odzyskaniu miasta w 1699 r.), 
prowadzona przez benedyktynki ormiańskie we Lwowie otrzymała prawa publiczne, straciła jednak charakter etniczny, gdyż przyjmowała uczennice różnych obrządków. Jedyną instytucją edukacyjną przekazującą ormiańskie dziedzictwo kulturowe stał się dla Ormian z Galicji wiedeński klasztor Mechitarystów, gdzie w XIX wieku uczyło się kilku duchownych. Kontakty z ormiańskim światem katolickim nie były jednak szczególnie intensywne. Wpłynęła na to również zmiana dróg handlowych, a co za tym idzie - zerwanie więzi ekonomicznych ze Wschodem. Zerwane zostały także dawne kontakty z Węgrami i Siedmiogrodem. Ormianie w Galicji żyli we własnym kręgu towarzyskim i w kręgu spraw polskich, utrzymując żywsze kontakty ze swymi rodakami na Bukowinie.

Stare dzielnice ormiańskie w miastach Galicji Wschodniej upadały, głównie na skutek opuszczenia ich przez Ormian, ale też w wyniku różnych klęsk żywiołowych. W 1778 roku we Lwowie pożar zniszczył większość kamienic przy ulicy Ormiańskiej, pałac arcybiskupi, mieszkania księży, klasztor Benedyktynek i szpital. Mimo odbudowy dzielnica ormiańska straciła dawny prestiż i zamieniła się w zrujnowany zaułek. Niewielkie zmiany w tym zakresie zaczęły się dopiero na początku drugiej połowy wieku. We Lwowie na przełomie XVIII i XIX stulecia liczba Ormian przekraczała zaledwie 200 osób ${ }^{13}$.

Reformy józefińskie zlikwidowały bariery społeczne i Ormianie zostali dopuszczeni do wszystkich urzędów miejskich i zawodów. Dzięki otwarciu nowych rynków tradycyjne inicjatywy handlowo-produkcyjne Ormian nabrały rozmachu. Powstawały nowe manufaktury. Handel i produkcja ormiańska w Galicji koncentrowały się na Mołdawii, południowej Rosji, krajach południowoniemieckich i austriackich. Fortuny ormiańskie rosły natomiast na dostawach koni i bydła dla armii austriackiej, bawarskiej i rosyjskiej w dobie wojen napoleońskich. Duże znaczenie dla wzrostu potencjału Ormian galicyjskich miało otwarcie dla kolonizacji i eksploatacji nowej prowincji Austrii - Bukowiny. Korzystali na tym głównie Ormianie z Pokucia i Podola, zwłaszcza ci, którzy przybyli do Polski w XVIII wieku. Zyski bukowińskie przeznaczano na zakup dóbr ziemskich. Ormianie kupowali majątki w najżyźniejszych okolicach zarówno na Bukowinie, jak i w Galicji Wschodniej, szczególnie na Pokuciu i Podolu. Największe fortuny powstały w pierwszej połowie XIX wieku. $\mathrm{O}$ ich trudnych początkach tak pisał Ludwik Jabłonowski:

Trzeźwo sądząc o rzeczach, a prawdziwą wartość dóbr upatrując w ziemi, szczególnie w sianach i paszach, sunąc ku nam od Bukowiny i Pokucia, w krótkim czasie nabyli najpiękniejsze

przeszli na język polski, którego używali od XVI w. także w stosunkach towarzyskich. Językiem ormiańskim władali natomiast Ormianie sprowadzani do Polski w XVII i XVIII w., głównie przez magnatów. Ormianie, podobnie jak inne grupy alochtoniczne, znali też różne dialekty języka ruskiego, czego ślady widzimy w zapożyczeniach leksykalnych w języku kipczackim. Badania nad mówionym językiem ormiańskim są słabo zaawansowane. Znany jest lepiej tylko dialekt ormiański z Kut, badany w drugiej połowie XIX w. przez Jana Hanusza. Zabytki języka ormiańskiego z innych ośrodków czekają dopiero na swoich badaczy i na razie niewiele na ten temat da się powiedzieć. Por. K. Stopka, Języki oswajane pismem. Alografia kipczacko-ormiańska i polsko-ormiańska w kulturze dawnej Polski, Kraków 2013.

13212 osób w 1783 r. i 208 w 1843 r. Por. S. Barącz, Rys dziejów ormiańskich, Tarnopol 1869, s. 141; Catalogus 1843, s. 10. 
majątki za bezcen. Niestety - gdy nie ma prawidła bez wyjątku - nie zawsze godziwymi sposobami. Pamiętam ja dobrze antenatów kilku ich rodzin jak: Bołoz-Antoniewicze, Abrahamowicze, Augustynowicze (herbu Odrowąż, bo są i inni) [...], jak siedzieli za ladami po składach sukien, win, bakalii, jak w zatłuszczonych kożuchach koło Starego Teatru [we Lwowie - przyp. K.S.] częstowali przechodni wyzem lub kawiorem, jak z kawałkiem koziny i bryłą huzuła w torbie ciągnęli skroczem za stadami wołów do Ołomuńca ${ }^{14}$.

W połowie XIX stulecia przezywano ich „kobzanami” lub „kabzanami”, co słowniki prowincjonalizmów polskich wywodziły od „kabzy”, czyli woreczka na pieniądze, w nawiązaniu do ormiańskiej chciwości na pieniądze ${ }^{15}$.

Nowa aktywność ekonomiczna doprowadziła do migracji i rozproszenia Ormian poza tradycyjne miejskie ośrodki etniczne. Nowi ziemianie przenieśli się do wiejskich dworów w pobliże dworów ziemian polskich. Nabywanie majątków ziemskich, a także austriackie kariery urzędnicze prowadziły ich do stanu szlacheckiego. Stosunkowo łatwo można było uzyskać szlachectwo na Bukowinie, z reguły w formie potwierdzenia urzędowego, co dawało pozór starodawnego jego posiadania. Ormianie galicyjscy powoływali się przed odpowiednimi urzędami austriackimi na prawdziwe lub rzekome szlachectwo polskie ${ }^{16}$, „odwieczne szlachectwo bukowińskie”, bądź kupowali sobie poświadczenia w mołdawskich Jassach. Natężenie tych nobilitacji i indygenatów dało się zaobserwować w latach 1779-1795, 1807-1820. W kolejnych dziesięcioleciach tylko jednostki uzyskiwały szlachectwo pierwszego lub drugiego stopnia, a jedynie sześć rodzin ormiańskich uzyskało tytuł baronowski ${ }^{17}$. Państwo austriackie chciało w ten sposób wykształcić lub wzmocnić poczucie lojalności w stosunku do siebie. Poczucie wspólnego interesu ekonomicznego ze szlachtą polską i tradycje kultury polskiej okazały się jednak silniejsze niż wdzięczność wobec władzy austriackiej za awans społeczny. Wnikanie do stanu szlacheckiego miało początkowo charakter czysto formalny, gdyż ormiańscy ziemianie nie od razu zostali zaakceptowani przez szlachtę polską. Ziemiaństwu pochodzenia ormiańskiego wytykano ,śmiesznostki” obyczajowe i wypominano nieszlacheckie pochodzenie fortun. Uważano ich za „Polaków pośledniejszego gatunku”, a więc takich, którzy dopiero powinni zdać egzamin z polskości ${ }^{18}$. Mimo zanikania tego stereotypu w drugiej

14 L. Jabłonowski, Pamiętniki, oprac., wstęp i przyp. K. Lewicki, Kraków 1963, s. 86.

15 K. Stopka, Ormianie w Polsce dawnej i dzisiejszej, s. 92.

16 Ormianie lwowscy uważali się za lepszych od Ormian sprowadzonych w XVIII w. na Pokucie i Podole, gdyż przypisywali sobie gremialnie pochodzenie od ormiańskich rodów rycerskich. Niewielka grupa rodzin ormiańskich została rzeczywiście nobilitowana w czasach polskich za męstwo wojenne (głównie w czasach wojen z Turcją) i wkład w rozwój przemysłu krajowego (w dobie oświecenia). Zob. J. Ritter von Bołoz-Antoniewicz, Die Armenier [w:] Die österreichisch-ungarische Monarchie in Wort und Bild, Bd. 19: Galizien, Wien 1898, s. 440-463; L. Korwin, Ormiańskie rody szlacheckie w Polsce, Kraków 1934; K. Stopka, Ormianie polscy-początki [w:] Ormianie, s. 13-44.

17 K. Stopka, Ormianie w Polsce dawnej i dzisiejszej, s. 92; idem, Ormianie w Galicji austriackiej, s. 85 .

18 K. Chłędowski, Pamiętniki, t. 2: Wiedeń (1881-1901), do dr. przygot., wstęp i przyp. A. Knot, Kraków 1951, s. 54. Zob. K. Stopk a, Ormianie w Galicji austriackiej, s. 97-100. 
połowie wieku określenie „Ormianin” nie straciło do końca pejoratywnej konotacji i było wykorzystywane w trakcie walk politycznych ${ }^{19}$.

Impulsem migracyjnym okazało się powstanie nowej warstwy społecznej - inteligencji. Proces ten otworzył nowe możliwości uboższym członkom społeczności ormiańskiej. Dzięki wykształceniu gimnazjalnemu, a często uniwersyteckiemu, wielu synów z rodzin ormiańskich znalazło zatrudnienie w zawodach urzędniczych, prawniczych, lekarskich, dziennikarstwie itd. Wykonywanie zawodów inteligenckich wiązało się często ze zmianą miejsca pobytu i obejmowaniem posad w różnych miastach galicyjskich, co osłabiało więzi etniczne. Udział w życiu politycznym stwarzał kolejną możliwość integracji Ormian z Polakami. Zaangażowanie to początkowo było skromne. Nieliczni Ormianie z Galicji popierali powstanie listopadowe, spiski z lat 30. i 40. XIX wieku oraz wydarzenia Wiosny Ludów w 1848 roku. Dopiero w drugiej połowie XIX stulecia, w dobie tak zwanej autonomii galicyjskiej, ormiańscy ziemianie i inteligencja zaangażowali się szerzej w życie polityczne. Ubożsi Ormianie na Pokuciu integrowali się też z Rusinami, a następnie z Ukraińcami, ale w tym wypadku tracili więzi i pamięć swego ormiańskiego pochodzenia. Ormianie, zwłaszcza ziemianie i inteligencja, definiowali swój interes grupowy w zgodzie $\mathrm{z}$ istniejącym establishmentem polskim, nie dążyli do obalenia aktualnych podziałów społecznych, a ich ambicje polityczne nie były sprzeczne z programem Polaków ${ }^{20}$. Co więcej, dzięki nim, poprzez mariaże spolonizowało się wielu galicyjskich Niemców i to już we wczesnym okresie panowania austriackiego. Na Bukowinie pojawili się nawet „Armeno-Polacy”, którzy w drugiej połowie XIX wieku otrzymali swą reprezentację w tamtejszym sejmie krajowym ${ }^{21}$.

Tuż przed rozbiorami nastąpiło ożywienie zainteresowań historią grupy, co było skutkiem działań oświeceniowych intelektualistów, słabo wspieranych jeszcze przez liderów etnicznych. Środowisko kościelne i starsi gminy przechowywali jednak pamięć grupową. Na przykład byli informatorami historyków spoza społeczności Ormian galicyjskich, którzy poszukiwali informacji na temat ich historii (Tadeusz Czacki, Howhannes Zohrab, Minas Byżyszkianc). Na początku wieku XIX historiografię ormiańską usiłował uprawiać ksiądz Mikołaj Moszoro, ambitny kandydat na arcybiskupa, potem administrator biskupstwa ormiańskokatolickiego w Mohylowie (Rosja) ${ }^{22}$. Ówczesny arcybiskup ormiański lwowski Kajetan Augustyn Warteresiewicz (1820-1831) gromadził armenica i przygotowywał słownik języka ormiańskiego. Ormianie obrządku łacińskiego - Franciszek Ksawery Zachariasiewicz, wykładowca historii Kościoła na Uniwersytecie Lwowskim, oraz znajdujący się u progu kariery dominikanin Sadok Barącz swą działalnością pisarską otworzyli nowy etap

19 A.A. Zięba, Patriotyzmy polskich Ormian, s. 57.

20 K. Stopka, Ormianie w Polsce dawnej i dzisiejszej, s. 93-95.

21 A.A. Zię ba, Idea powrotu Ormian z rozproszenia do narodowego państwa w historycznej ojczyźnie $w$ świetle memoriału Roberta Bogdanowicza z 1884 roku (w druku).

22 Biblioteka Czartoryskich, sygn. 2298 I: Historia krótko zebrana o narodzie i królestwie ormiańskim. 
badań nad przeszłością Ormian polskich ${ }^{23}$. Ogólnie rzecz biorąc, nie interesowano się zbytnio losami archiwaliów, które marniały, przechodziły jako podarunki w prywatne ręce lub do zbiorów publicznych. Jakaś ich część trafiła do Tadeusza Czackiego, inne podarowano Zakładowi Narodowemu im. Ossolińskich we Lwowie, jeszcze inne trafiły do mechitarystów w Wenecji i w Wiedniu.

Aż do połowy XIX wieku refleksja na temat tożsamości Ormian galicyjskich nie miała form publicznych. Jej przemiany odbywały się w niemal kompletnej ciszy. W listach i cyrkularzach arcybiskupów ormiańskich z tego okresu brak treści odnoszących się do własnych tradycji etnicznych, choćby w aspekcie religijnym. Na przykład posłania Samuela Cyryla Stefanowicza, długoletniego i bardzo poważanego arcybiskupa lwowskiego, niezwykle popularnego jako kaznodziei i spowiednika także wśród łacinników, wydawane $\mathrm{z}$ okazji ogólnokatolickich, pisane w języku polskim, były poświęcone uniwersalnym zagadnieniom moralno-religijnym ${ }^{24}$.

Zmiana nastąpiła na początku lat 60. XIX wieku, gdy opinią społeczności ormiańskiej wstrząsnęło ukazanie się Głosu do ziomków obrządku ormiańskokatolickiego ${ }^{25}$. Personalia autora tej pierwszej propozycji programowej dla Ormian polskich, sformułowanej w języku nowoczesnego pojmowania spraw narodowych, pozostają niewyjaśnione. Autor nie zdecydował się bowiem wyjść z cienia anonimowości ${ }^{26}$.

Czas ogłoszenia broszury zbiegł się z manifestacjami patriotycznymi w Królestwie Polskim, poprzedzającymi wybuch antyrosyjskiego powstania. Był to więc czas wielkiej mobilizacji psychicznej wśród Polaków, w którym rozlegały się apele o solidarność w walce z zaborcą o odbudowanie niezależnej Polski wszystkich mieszkańców jej przedrozbiorowego terytorium, bez względu na wyznawaną religię i pochodzenie etniczne. Równolegle zachodziły intensywne przemiany wśród Żydów monarchii habsburskiej, zmierzające w kierunku narodowej i kulturalnej asymilacji ze społeczeństwami poszczególnych krajów koronnych - niemieckim, węgierskim, czeskim, polskim. Główna idea Głosu do ziomków..., czyli wezwanie do porzucenia obrząaku ormiańskiego i całkowitego zlania się z Polakami, była pochodną tego, co działo się w Królestwie Polskim, i zjawiskiem analogicznym do trendu

23 X.Z. [F.K. Zachariasiewicz], op. cit.; S. Barącz, Żywoty sławnych Ormian w Polsce, Lwów 1856; idem, Pamiątki miasta Żótkwi, Lwów 1852; idem, Pamiętnik dziejów polskich z akt urzędowych lwowskich i rękopisów, Lwów 1855; idem, Pamiątki miasta Stanisławowa, Lwów 1858; idem, Pamiątki jazłowieckie, Lwów 1862 i liczne inne. O Sadoku Barączu zob. M. Miławicki, ,Świat ode mnie zawsze rzeczy nadzwyczajnych wymagat, a ponadto nieslusznie”. O. Sadok Wincenty Baracz (1814-1892) w świetle źródet, „Lehahayer” 2013, nr 2, s. 153-197.

24 Zob. listy z 10 VII 1832, 15 II 1851, 4 III 1852, 26 IV 1858. Zob. K. Stopka, Stefanowicz Samuel Cyryl [w:] Polski stownik biograficzny, t. 43, Warszawa-Kraków 2005, s. 211-216.

${ }_{25}$ Głos do ziomków obrządku ormiańsko-katolickiego, Lwów 1861.

26 Autorstwo przypisywano kilku osobom. Według Stanisława Estreichera autorem był Michał Torosiewicz, ziemianin, właściciel miasteczka Sassów w Galicji wschodniej. Według innej wersji, podanej Czesławowi Lechickiemu przez księdza Dawida Dawidowicza, miał nim być inny Torosiewicz, Emil, również ziemianin i późniejszy parlamentarzysta galicyjski. Pojawiły się też domysły, że autorstwo broszury należy przypisać Polakowi, podawano nawet nazwisko niejakiego Błażowskiego. Zob. K. Estreicher, Bibliografia polska XIX wieku, t. 4, Kraków 1916, s. 517; nekrolog Emila Torosiewicza: „Kraj” 1901, nr 7, s. 22; S. Barąc z, Rys dziejów ormiańskich, s. 200; Cz. Lechicki, Kościół ormiański w Polsce, s. 131-133. 
asymilacyjnego wśród Żydów europejskich. Autor Głosu do ziomków... sugerował też, że geneza jego przemyśleń łączy się z burzliwymi dyskusjami toczonymi w dobie Wiosny Ludów na temat tego, czym jest naród polski dla Rusinów, Ormian czy Żydów galicyjskich. Główna teza propagowana w 1848 roku przez polskich patriotów, a wielu $\mathrm{z}$ nich pochodziło $\mathrm{z}$ tych grup mniejszościowych, była identyczna $\mathrm{z}$ tą, którą głoszono przed powstaniem styczniowym: podporządkowanie różnych etniczności, regionalizmów, wspólnot religijnych, polskiej politycznej idei narodowej.

Autor Głosu do ziomków... już w tytule, zwracając się do „ziomków obrządku ormiańsko-katolickiego", i we wstępnej uwadze, że jego propozycja „nie będzie obojętną dla naszych współziomków wszelkich obrządków”, niedwuznacznie dawał do zrozumienia, że Ormian galicyjskich uważa za członków szerszego ziomkostwa, to jest wspólnoty narodowej Polaków ${ }^{27}$. W Głosie do ziomków... Austria zdaje się w ogóle nie istnieć, a o Polsce - wtedy tylko bycie postulowanym - pisze się zawsze w czasie teraźniejszym. Autor uważał, że nie ma podstaw do określenia się przez Ormian galicyjskich jako odrębnej narodowości i uzasadnienia dla utrzymywania osobnej nazwy narodowej. Starał się zdefiniować pojęcie narodu i poddawał analizie różne cechy tożsamości narodowej, dochodząc do wniosku, że język, obyczaje, dzieje, świadomość narodowa i zaangażowanie patriotyczne nie dzielą Ormian i Polaków. Tak o tym pisał:

Język polski jest naszą mową ojczystą, wszakże nie nabywamy go nauką, tylko jeszcze w kolebce. W tym języku [...] odbieramy pierwsze nauki wiary, w tym modlimy się, w tym przemawia do nas ksiądz z kazalnicy i przy udzielaniu nam świętych sakramentów od chrztu aż do ostatniego namazania, wiodącego nas do zbawienia. Obyczaje nasze w pożyciu domowym i towarzyskim noszą cechę polską, dzieje nasze od ośmiu wieków ściśle są wplecione w dzieje tej ojczyzny, w której żyjemy, tej ojczyzny, którą kochamy sercem i czynem i która nas do wiernych synów policzyć może $e^{28}$.

Będąc świadom istnienia wyjątku od reguły, perswadował:

A że kilka biednych rodzin w mieścinie Kutach, i to tylko w kółku domowym, mówi jeszcze zepsutym i dla Ormian z Orientu niezrozumiałym językiem, to jeszcze za objaw życia narodowego uważanym być nie może, ileże i w tych Kutach kapłan w kościółku ormiańskim tylko po polsku z kazalnicy do ludu przemawia ${ }^{29}$.

Za najdobitniejszy przykład jedności Ormian z narodowością polską uważał sytuację na Bukowinie, gdzie mimo przewagi liczebnej kultur ludowych (ruskiej, rumuńskiej) i politycznej dominacji „kosmopolitycznej inteligencji”, Ormianie nie przeistaczają się ani w kosmopolitów, ani w Rusinów lub Rumunów, lecz trzymają się „żywiołu polskiego" i są głównym oparciem dla języka polskiego w tej prowincji. Pamięć historyczna dla autora Głosu do ziomków... to dzieje Ormian w Polsce, a nie w dalekiej Armenii, i udział we wszystkich wielkich sukcesach i klęskach Polski, zarówno gdy była ona imperium, jak i podczas zrywów niepodległościowych doby niewoli narodowej.

\footnotetext{
27 Gtos do ziomków..., s. III-IV.

28 Ibidem, s. 5.

29 Ibidem, s. 7.
} 
Historia polska umieszczała zawsze wszystkie znakomitości pochodzenia ormiańskiego w poczet swoich ludzi sławnych, i to słusznie, bo też sława ich zapisaną jest w dziejach Polski i nosiła cechę narodowości polskiej, a nie ormiańskiej ${ }^{30}$.

Twierdził, że Polska do tego stopnia stała się ojczyzną Ormian, że ich pozycję w niej trzeba uznać za ,bezprzykładną prawie w stosunkach międzynarodowych”. Żywioł ormiański - pisał - ,jest dziś w Polsce tylko trupem zgasłej od wieków narodowości ormiańskiej, trupem, który już dawno powinien być złożony w grobie zgasłych narodów”. Stwierdzał, że „naród w narodzie swobodnie istnieć i rozwijać się nie może", a jeżeli próbuje to robić, to albo sytuuje się „,na jakimś podrzędnym stanowisku”, albo „obudza niechęć, a częstokroć i zazdrość”31.

Aby usunąć tę ,anomalię" niezrozumiałą dla ludzi z zewnątrz, za jaką autor uważał nazywanie rzeczywistych Polaków Ormianami, należałoby zlikwidować „,zupełnie niepotrzebny obrządek”. Dowody na to znajdował liczne: przechodzenie księży ormiańskich na obrządek łaciński, brak własnego seminarium, ucieczka wiernych lub uchylanie się od przestrzegania obrządku w małżeństwach mieszanych, konieczność stosowania przez instancje kościelne drogi prawnej do odzyskania jurysdykcji obrządkowej nad takimi osobami. Negował też dane liczbowe podawane przez środowisko kościelne, twierdząc, że większość parafii liczy tylko kilkadziesiąt, a niektóre zaledwie kilkanaście dusz. Według niego we Lwowie było 95 parafian. Warto przytoczyć w tym miejscu jego charakterystykę głównego kościoła ormiańskiego:

[...] katedra położona w zaniedbanej dzielnicy miasta, ukryta nagimi murami przed widokiem, przypomina katakumby i wygląda jak niegdyś kościółki pierwszych chrześcijan tolerowane przez władze, a ukrywane przed okiem ludu. Kościół na zewnątrz opuszczony, a wewnątrz najczęściej próżny, nie odwiedzany nawet przez małą garstkę parafian [...], zdradza obojętność do swego obrządku².

Ten stan rzeczy uważał za dowód upadku zasad moralnych, gdyż większość wiernych traciła kontakt z duszpasterzami. Kolejnym argumentem przemawiającym za likwidacją obrządku było dla autora Głosu do ziomków... zjawisko zamykania się ziemian i inteligencji pochodzenia ormiańskiego w swoistym getcie rodzinno-obrządkowym, co tamowało ich naturalną energię społeczną i powstrzymywało od wpływu i stanowisk w kraju, jakie się im przynależą. Obrządek stanowił też - według niego - przyczynę fizycznej degeneracji, gdyż od wieków skłaniał do endogamii. Wspominał, że dopiero od pół wieku mieszane małżeństwa są częstsze i ,wywierają dobry wpływ na potomstwo"33. Obrządek miał uzasadnienie wtedy, gdy łączył się z samorządem gminnym i - jeszcze wcześniej - gdy istniała nadzieja na powrót do pierwotnej ojczyzny, ale obie te okoliczności, według autora, znikły. Likwidację obrządku proponował przeprowadzić przez stworzenie nowej diecezji łacińskiej w Stanisławowie lub w Czerniowcach, której zwierzchnikiem zostałby ostatni arcybiskup

\footnotetext{
Ibidem, s. 12.

31 Ibidem, s. 8-9, 12.

32 Ibidem, s. 16.

33 Ibidem, s. 13.
} 
ormiański ${ }^{34}$. Widać jednak, że autor był świadom, jak silna opozycja wobec jego tezy może powstać ze strony „armenistów”. Tą nazwą określał Ormian, którzy uważali swój obrządek za oznakę osobnej narodowości. Uprzedzając protesty, przypominał, że Polacy wyznania kalwińskiego są równie polscy jak Polacy-katolicy, że Polakami stają się nie tylko niezliczone ,rodziny niemieckiego pochodzenia i nazwiska”, i to „W pierwszym pokoleniu”, ale „nawet Żydzi w Warszawie przybierają już barwę i poczucie narodowości polskiej”. Z potępieniem wyrażał się o „kastyjnych namiętnościach kilku sekciarzy", którzy usiłowali lud obrządku greckokatolickiego oderwać od ojczyzny polskiej, i wreszcie stwierdzał, że „nierównie większego przymusu wymaga [od nas] zaparcie się żywiołu polskiego, w którym żyjemy, niż ormiańskiego, który jest nam równie jak ziomkom Polakom zupełnie obcy"35.

Broszura poruszyła usypiającą ormiańskość galicyjską. Zastrzeżenia zgłosili Polacy sprzyjający obrządkowi ormiańskiemu, jak ksiądz Aleksy Prusinowski w wielkopolskim „Tygodniku Katolickim”36 oraz literat i geograf Wincenty Pol. Do frontalnej rozprawy z tezami anonima przystąpił ksiądz Izaak Mikołaj Isakowicz, wówczas wikary ormiański w Stanisławowie ${ }^{37}$.

Ksiądz Isakowicz w Odprawie autorowi broszury „Głos do ziomków”38 zaprzeczał, jakoby reprezentował on przekonania ogółu Ormian galicyjskich. Sugerował, że jest on wyrazicielem zaledwie kilkunastu rodzin tego obrządku, i to tych najbogatszych, chcących się stać arystokracją w „hierarchii rodowej wśród narodu, który tak gościnnie przodków naszych przyjął”. Twierdził dalej, że owych „armenistów”, czyli zwolenników obrządku, jest „nieporównywalnie więcej wśród Ormian, niż tych, którzy chcieliby się z nim pożegnać" ${ }^{39}$. Polemizował z tezą, jakoby nie było już w Galicji Ormian mówiących w domu językiem etnicznym i przestrzegających własnego obyczaju: „Są jeszcze Ormianie, którzy po dziś dzień mówią własnym swoim językiem, osobliwie lud prosty w Kuttach, Śniatynie, Suczawie i na całej Bukowinie mieszkający; językiem dobrze zrozumiałym dla Ormian z Orientu" ${ }^{\prime 4}$. I dalej:

Wszak Ormianie w Kuttach, Śniatynie, Suczawie i na całej Bukowinie mieszkający mówią jeszcze, jak żeśmy to wyżej powiedzieli, tak dobrze językiem Ormiańskim, żeby snadnie tym językiem można nawet do nich kazać z ambony. W kościołach owych parafialnych odprawiają oni z kapłanami swoimi wspólnie jutrznię i nieszpory w języku ormiańskim; z kapłanami wspólnie odprawiają, w języku ormiańskim wszystkie nabożeństwa zaduszne przy pogrzebach i mszach rekwialnych. Lud ten kocha namiętnie wszystkie czcigodne zwyczaje i obyczaje swego obrządku... ${ }^{41}$

34 Ibidem, s. 20.

5 Ibidem, s. 23-26.

36 „Tygodnik Katolicki” 1861, nr 20.

37 T. Zaleski, Biskup ormiański Izaak Mikołaj Isakowicz „Złotousty”, Kraków 2001; idem, Stownik biograficzny duchownych ormiańskich w Polsce, Kraków 2001, s. 50-52.

38 I. Isakowicz, Odprawa autorowi broszury , Głos do ziomków obrządku ormiańsko-katolickiego”, Wiedeń 1861.

39 Ibidem, s. 3-4.

40 Ibidem, s. 5.

41 Ibidem, s. 14-15. 
Przypominał, że rysy twarzy nawet tych całkowicie spolonizowanych Ormian zdradzają orientalne pochodzenie (,sam rys wybitny naszej twarzy zdradza koniecznie nasze orientalne pochodzenie”). Odpierając zarzut formowania „szkodliwego separatyzmu" względem Polaków, odżegnywał się od intencji budowania osobnego „narodu w narodzie” i twierdził, że utrzymywanie własnego rytu liturgicznego i związanych z nim tradycji kulturowych nie oznacza tworzenia osobnej narodowości. W broszurze księdza Isakowicza znajdujemy gorącą apologię narodu polskiego jako narodu „gospodarza”, który stał się drugą ojczyzną dla Ormian.

Uchodząc z własnej ojczyzny, jako tułacze i sieroty, znaleźli oni w tej ziemi, na której się osiedlili, nie macochę, ale matkę prawdziwą, dlatego też całym sercem i całą duszą jak do swej matki, do niej się przywiązali, zowiąc ją odtąd drugą swoją ojczyzną. Naród szlachetny, który im w ich niedoli otworzył swe serce, i do swego łona ich przytulił, który ich wzywał i zapraszał do swych grodów i obdarzał ich świetnymi przywilejami, ukochali oni jakby ojca swego i brata; dlatego też wdzięcznością przejęci ku pospolitemu dobru tego narodu pracowali, dzielili wiernie wszystkie szczęsne i nieszczęsne koleje jego losu; z nim razem cieszyli się oni w dniach jego szczęścia, z nim razem boleli i cierpieli oni w dniach jego niedoli. Uczeni Ormiańscy jako synowie nowej ojczyzny swojej dla dobra tejże poświęcali swe talenty, swe prace literackie, czujący w sobie powołanie do rycerskiego rzemiosła stawali wspólnie z innymi w obronie wiary świętej i ojczyzny ${ }^{42}$.

Dla księdza Isakowicza równie droga i godna miłości była także tożsamość ormiańska. Uważał uczucie względem niej za zupełnie niekonfliktowe wobec polskości i uzasadnione racjami historycznymi oraz religijnymi.

Pochodzimy albowiem z narodu - uzasadniał - który na pierwszych kartach pisma Bożego jest już zapisany, który świetnym narodowym życiem przeżył wiele wieków, który w obronie wolności, narodowości i niepodległości swej staczał wiele krwawych bitew [...] i odpierał dzielnie wszelkie zamachy na swój byt narodowy. [...] Pochodzimy z narodu, który już za czasów apostolskich był po części chrześcijański, bo święci Apostołowie Tadeusz i Bartłomiej rzucili pierwsze nasiona wiary Zbawiciela na ziemię jego, a ostatni męczeńską nawet śmiercią wśród Ormian dokonał swego apostolskiego żywota; pochodzimy z narodu, który na początku już czwartego wieku był cały chrześcijański. [...] Miano nasze „Ormian” jest dla nas zaszczytem i chlubą, relikwią drogą, którą tak długo, jak można tylko, zachować należy. [...] Więc nie widzimy żadnej zgoła potrzeby wstydzenia się nazwy naszej Ormian, i zmiany na inny obrządku naszego ormiańskiego, w którym jesteśmy zrodzeni i wychowani ${ }^{43}$.

Broniąc obrządku, pisał tak:

[...] Język ormiański używany w obrządku naszym dla wielkiej części prostego ludu ormiańskiego jest choć w części zrozumiałym, bo lud nasz prosty mówi dotychczas jeszcze językiem ormiańskim, którego stosunek do liturgicznego języka naszego jest prawie ten sam, co między mową ludową ruską a językiem starocerkiewnym $[\ldots]^{44}$.

Uważając swój punkt widzenia za realistyczny, jeżeli chodzi o nastroje panujące wśród Ormian galicyjskich, podkreślał jednocześnie, że wyraża szczególne potrzeby narodu polskiego w Galicji Wschodniej. Radykalne zarzucenie obrządku

\footnotetext{
42 Ibidem, s. 5.

43 Ibidem, s. 7-8, 20.

44 Ibidem, s. 10.
} 
ormiańskiego nie zyskałoby, według niego, poparcia warstwy plebejskiej, która trwała przy kulturze etnicznej. A gdyby znikł ten wyróżnik, będący jednocześnie pomostem ku polskości, Ormianie mieszkający na wsiach i w małych miasteczkach wschodniogalicyjskich, na co dzień komunikujący się z ludową kulturą ruską, pozbawieni ochronnych ram własnego obrządku, łatwo mogliby zaakceptować obrządek greckokatolicki, a przez to w przyszłości stać się Rusinami. W tym czasie oznaczało to groźbę opowiedzenia się za opcją rusofilską, a więc w przyszłości za narodowością rosyjską.

Ksiądz Isakowicz słusznie zwracał uwagę na to, że Stolica Apostolska była żywotnie zainteresowana istnieniem obrządku ormiańskokatolickiego, zarówno ze względu na nadzieje co do pozyskania chrześcijan na Bliskim Wschodzie, jak też z uwagi na swe ambicje misyjne na Bukowinie $\mathrm{i}$ w krajach rumuńskich. $\mathrm{Z}$ tego względu Kościół katolicki nigdy obrządku ormiańskiego nie zlikwiduje - pisał - gdyż potem żaden chrześcijanin wschodni nie uwierzyłby w obietnice utrzymania własnych tradycji po przyjęciu unii z łacinnikami. Przypominał, że gdy tuż przed śmiercią arcybiskupa Stefanowicza (1858) chodziły słuchy o zamiarach władz austriackich zlikwidowania arcybiskupstwa lwowskiego, zapobiegła temu szybka nominacja papieska dla księdza Grzegorza Szymonowicza na koadiutora przy sędziwym arcybiskupie ${ }^{45}$. Starożytność obrządku ormiańskiego sięgającego czasów apostolskich i Grzegorza Oświeciciela (IV w.) była bardzo cenna dla Kościoła katolickiego. Pytał też, odwracając argument autora Głosu do ziomków..., dlaczego akurat Polacy obrządku ormiańskiego mają z niego rezygnować, skoro nie robią tego Polacy wyznania luterańskiego, kalwińskiego czy mojżeszowego. Zwracał uwagę, że ormiańskość nie jest powodem żadnych negatywnych uprzedzeń, poniżeń czy upośledzeń, ani ze strony „ludu prostego”, ani „obywateli Polaków”. Oburzenie wzbudziło u księdza Isakowicza podejrzenie, że diecezjalne szematyzmy (katalogi kleru) ormiańskie zawyżają liczbę wiernych. $Z$ tego powodu uznał wypowiedź anonima za obrazę arcybiskupa, duchowieństwa i całej społeczności, bo zarzucała duchowieństwu kłamstwo i lenistwo, a wiernym „fizyczną degenerację"46.

Autor Gtosu do ziomków... próbował kontynuować polemikę. Jego odpowiedź ukazała się jeszcze w tym samym roku ${ }^{47}$. Zarzucił księdzu Isakowiczowi chęć „obałamucenia współziomków i opinii publicznej”. „Znalazłem tam wszystko oprócz prawdy" - pisał o Odprawie... Skoncentrował się na niewątpliwie najsłabszym argumencie obrońców ormiańskości w Galicji: znajomości języka etnicznego. Zarzucał swemu polemiście, że choć jest tak gorliwym zwolennikiem utrzymania obrządku, do tej pory nie nauczył się języka i dlatego nie potrafiłby nawracać bukowińskich Ormian niekatolików, którzy go nadal używali. Pozornie ta replika pozostała bez odpowiedzi.

W istocie wszystko to, co potem duchowni ormiańscy w Galicji robili, było próbą zaprzeczenia jej tezom i heroiczną próbą naprawienia zaniedbań na polu etnicznym,

45 Ibidem, s. 18-19.

46 Ibidem, s. 22-29. Anonimowo ogłoszoną Odprawę... autor podpisał: „Stanisławów na Pokuciu, 16 czerwca 1861, w dzień św. Grzegorza Apostoła, Patriarchy i Oświeciciela Ormian”.

47 Odpowiedź księdzu Isakowiczowi, Lwów 1861. 
które im wytknięto. Już w 1862 roku ksiądz Isakowicz wydał list otwarty na temat nawracania Ormian bukowińskich na katolicyzm, napisany w języku ormiańskim. Miał też podjąć, według swego biografa, misję w Suczawie ${ }^{48}$. Czy jednak opanował język swych przodków i etnicznych rodaków, jest bardzo wątpliwe, ponieważ poza tym jednym epizodem, zarówno wcześniej, jak i potem, mówił i pisał wyłącznie po polsku ${ }^{49}$. Arcybiskup Grzegorz Szymonowicz nie potrafił porozumieć się podczas I soboru watykańskiego (1869-1870) z żadnym z 27 biskupów ormiańskokatolickich pochodzących z Bliskiego Wschodu. Nie znał bowiem języka ormiańskiego ani francuskiego, a oni z kolei - niemieckiego ani polskiego ${ }^{50}$.

Społeczność ormiańskokatolicka nie mogła zapomnieć o Glosie do ziomków... Ksiądz Sadok Barącz kilka lat potem pisał: „, [... jedno tylko złe stało się, że rozmazano błazeństwa pamfletu, którego Ormianin nie był autorem. Ormianie poczciwi, a nadzwyczaj roztropni nie mogli takich głupstw uwłaczających rozumowi, prawu natury i oświacie wieku XIX pisać" ${ }^{51}$. Praca, w której te słowa zawarł, była pomyślana jako rozbudowane i solidnie uargumentowane dowodami historycznymi zaprzeczenie tezie, że Ormianie w Galicji nie czują się Ormianami. Nawet odwołanie się do „natury i oświaty wieku XIX” było odwetem za epitet, którym autor Głosu do ziomków... obdarzył księdza Isakowicza, że broniąc obrządku, chce on „przytłumić prawdę nie dającą się już w XIX wieku zatrzeć płaszczem fanatycznej i ponurej średniowieczyzny" ${ }^{2}$. Poniekąd więc znany i cytowany do dziś Rys dziejów ormiańskich księdza Barącza, pozycja klasyczna w historiografii Ormian polskich, to także polemika z Głosem do ziomków... Anonimowemu autorowi Głosu do ziomków... zawdzięczamy ocalenie pamięci o przeszłości polskich Ormian, gdyż wiele ze źródeł wykorzystanych przez księdza Barącza do udowodnienia błędów zawartych w Głosie do ziomków... nie przetrwało późniejszych kataklizmów dziejowych. Polemika $\mathrm{z}$ autorem Głosu do ziomków... uczyniła z księdza Isakowicza autorytet obrządkowy i przyczyniła się to tego, że w 1882 roku został arcybiskupem, ale główny problem sporu: ucieczka wiernych od obrządku ormiańskiego do łacińskiego, trwał. W 1875 roku nuncjusz papieski w Wiedniu Lodovico Jacobini pisał: „Bardziej wykształcona część Ormian nie trzyma się chętnie swego obrządku, ale skłania się do tego, by była włączona do obrządku łacińskiego"s3.

W związku z nominacją arcybiskupią Izaak Mikołaj Isakowicz napisał list do kardynała Mieczysława Ledóchowskiego, szefa Kongregacji Rozkrzewiania Wiary. Deklarował w nim: ,[...] my Ormiano-Polacy od pięciu, sześciu wieków mieszkający na tych terenach tu mamy swą ojczyznę, na wschód nie chce żaden z nas wrócić" 54 . W tych słowach kryło się usprawiedliwienie pewnej dwuznaczności stanowiska

48 Cz. Lechicki, op. cit., s. 132.

49 Z. Zaleski, Biskup ormiański Izaak Mikołaj Isakowicz..., s. 39.

50 R. Bogdanowicz, Kwestya Kościoła obrzadku ormiańskiego i tegoż postannictwa jakoteż Kwestya Armeńska na wschodzie w ich własnym kraju, Brzeżany 1884, s. 13.

51 S. Barącz, Rys dziejów..., s. 200.

52 Odpowiedź księdzu Isakowiczowi, Lwów 1861, s. 12.

53 G. Petrowicz, op. cit., s. 336.

54 Ibidem, s. 357. 
obrońców obrządku ormiańskiego. Dlaczego go bronili, jeśli się uważali za Polaków? Może w rzeczywistości mieli inne poglądy niż autor Głosu do ziomków...? Jeżeli chodzi o księży Isakowicza i Barącza, podejrzenie takie jest niesłuszne. Aby tożsamość ormiańska mogła się stać rywalką polskiego patriotyzmu, należało we wspólnocie tego obrządku obudzić łączność ze wschodnią ojczyzną przodków, tak jak to się stało potem z Żydami polskimi, wabionymi ideologią syjonizmu. W przypadku Ormian nie było to zadanie zbyt realistyczne, choć znaleźli się ludzie, którzy rozważali taką opcję.

Świadczy o tym kolejna broszura autorstwa galicyjskiego Ormianina, która ukazała się w roku 1884. Napisał ją Robert Rosco-Bogdanowicz (1810 - po 1884), bogaty ziemianin spod Brzeżan, właściciel Litatyna, pochodzący z rodziny nadal ściśle przestrzegającej zasad endogamii. Wszystkie jego babki, prababki i praprababki były Ormiankami. On sam został ożeniony z kuzynką Serafiną Rosco-Bogdanowicz. „Zacny obywatel miłujący zabytki narodowe" 55 - jak go nazywał biograf - zajmował się studiami historycznymi nad przeszłością nie tylko Ormian polskich, ale też Ormian w ogóle. W latach 50. XIX wieku we lwowskim czasopiśmie „Przyjaciel Domowy” ogłosił pod pseudonimem „Dionizy Ostrowiecki” kilka przyczynków na temat miasta Ani (średniowiecznej stolicy Armenii), katolikosa Nersesa i instytucji armenologicznych w Europie Zachodniej ${ }^{56}$. Jego poglądy wykształciły się w dobie ożywienia „kwestii ormiańskiej” na Bliskim Wschodzie. Irredenta ormiańska wiązała wielkie nadzieje na odbudowę państwa narodowego dzięki pomocy Rosji (wojny z Persją i Turcją w latach 20. XIX w., rozejm w San Stefano, kongres berliński w 1878 r.). Silne poczucie solidarności etnicznej oraz wspomniane wysiłki przekształciły Bogdanowicza w programowego rusofila. Według tradycji rodzinnej był zażartym przeciwnikiem Austriaków i Niemców, miał ich uważać „za najwięcej nieprzejednanych i najniebezpieczniejszych wrogów Polski”. Podobno też stwierdził: „Musimy kiedyś dojść do porozumienia z Rosją jako narodem słowiańskim, którego polityka eksterminacyjna wobec Polski musi z czasem ulec ewolucji”. Antyrosyjskie powstanie polskie z 1863 roku uważał za błąd polityczny i ,nie wahał się przy każdej sposobności gwałtownie przy tym się upierać, co jego rozmówców oburzało"57. Te opinie pochodzą ze wspomnień Mariana Rosco-Bogdanowicza, szambelana cesarskiego, niepodzielającego ormiańskich fascynacji stryja-wuja i we własnych, polskich kategoriach narodowych prezentującego jego przekonania polityczne. $Z$ owych wspomnień wiemy także, iż poprzez polskiego sąsiada, hrabiego Stanisława Potockiego, który był koniuszym dworu cesarskiego w Petersburgu, Robert Rosco-Bogdanowicz nawiązał kontakt z kilkoma wysokiej rangi politykami rosyjskimi, szczególnie z ministrem spraw wewnętrznych cara Aleksandra II, generałem Michaiłem Tariełowiczem LorisMelikowym, z pochodzenia Ormianinem. Korespondowali ze sobą po francusku; niestety, listów tych na razie nie udało się odnaleźć. Loris-Melikow był autorem projektu

55 S. Barącz, Rys dziejów..., s. 199.

56 „Przyjaciel Domowy” 1855, 1856; S. Barącz, Rys dziejów..., s. 199.

57 M. Rosco-Bogdanowicz, Wspomnienia, oprac. J. Gintel, t. 1, Kraków 1859, s. 10-13; t. 2, Kraków 1859, s. 452. 
reform liberalnych w Rosji, które zdezaktualizował zamach na cara Aleksandra II (1881).

Bogdanowicz miał zupełnie inny stosunek do przeszłości narodowej. Ujmował ją nie tylko w kontekście historii diaspory ormiańskiej w Polsce. Miał poczucie misji historycznej narodu ormiańskiego jako przedmurza cywilizacji europejskiej oraz jego martyrologii, nawoływał do odbudowy tożsamości etnicznej Ormian galicyjskich, a szczególnie odrodzenia językowego. Język był dla niego głównym, obok religii i pamięci historycznej, filarem narodowości.

Nie jest to - pisał z wyrzutem - obowiązkowy [w seminarium duchownym - przyp. K.S.] język dla nauki i od tegoż examina nie są zdawane, przez co i żywioł obrządkowy Kościoła ormiańskiego pochylać się poczyna i odwraca się zupełnie od swego posłannictwa, który mu był przez Kościół katolicki nadany ${ }^{58}$.

Przez nieznajomość języka zerwana została - jego zdaniem - łączność z dawną ojczyzną, nawet z katolikami ormiańskimi na Bliskim Wschodzie. Winą za zanik języka obarczał Austrię, która po pierwszym rozbiorze Polski zlikwidowała kolegium dla kandydatów na księży ormiańskich, prowadzone przez teatynów we Lwowie. Teatynów nazywał ,armenistami”, bo kultywowali ormiańskie dziedzictwo kulturowe. Fakt ten „o wiele cofnął intelektualny stan naszego kleru i oziębił naród ormiański w pojęciach patriotycznych tyczących się Kościoła i obrządku, przeto wzmógł się nawet i szkodliwy indyferentyzm dla starożytnej liturgii obrządku ormiańskiego" 59 .

Nadzieję na odnowienie języka wśród Ormian polskich upatrywał Bogdanowicz w Zakładzie Naukowym im. Józefa Torosiewicza, założonym w 1865 roku przez bogatego lekarza i społecznika ormiańskiego we Lwowie. Była to bursa dla ubogiej młodzieży ormiańskiej. Bogdanowicz uważał, że:

[Zakład Naukowy im. J. Torosiewicza - przyp. K.S.] przeistoczony w czysty instytut ormiański [...] zdoła wywrzeć bardzo zbawienny wpływ na uczącą się młodzież ormiańską, bowiem takowa przywłaszczy sobie wiedzę języka ormiańskiego i wtedy czerpać będzie z pism ojczystych wiadomości o swojej starożytnej przeszłości, o swoim kraju i o losach swego narodu; duch młodzieży wówczas przejmie się gorącym patriotyzmem i młodzież ta stanie się przywiązaną i wierną córką swojego Kościoła i obrządku ${ }^{60}$.

Poważanie obrządku łacińskiego, a lekceważenie ormiańskiego nazywał

[...] policzkowaniem samych siebie, [bo] poniżając swój Kościół i obrządek, poniżamy się w oczach tych, do których się nieproszeni garniemy [...], alboż to obrządek łaciński ma być lepszy od ormiańskiego? [...] Bądźmy Ormianami, nie polaczmy się, a naszą skromnością, pracą i nauką, stałością i prawością, zdobędziemy sobie powszechny szacunek i uznanie, na które zaufanie od współobywateli sobie zasłużyliśmy, gdy bez różnicy zostajemy obierani na

58 R. Bogdanowicz, Kwestya Kościoła..., s. 9.

59 Ibidem, s. 8.

60 Ibidem, s. 33. Odnowicielem znajomości języka miał być - według jego projektów - mechitarysta Bartłomiej Kostecki, który pracował wśród Ormian katolików w Smyrnie, a w tym czasie (18821895) był administratorem parafii ormiańskiej w Tyśmienicy. Zob. T. Zaleski, Słownik biograficzny..., s. $64-65$. 
krzesła poselskie [do Sejmu Krajowego galicyjskiego - przyp. K.S.] i liczymy teraz jedenastu deputowanych z naszego maleńkiego grona i naszej narodowości ${ }^{61}$.

Jako odstraszający przykład przywoływał proces polonizacji bojarów ruskich, zakończony całkowitym wyparciem się miana Rusinów, choć Ruś - jak pisał - to naród i kultura, „które nie dadzą się z historii zatrzeć i zamazać”. Przebija tu sympatia do rusofilskiej wtedy inteligencji Rusinów galicyjskich i jej pretensji do polskiej szlachty wschodniogalicyjskiej, że:

z dawnych panów i ruskich bojarów, z elity tego narodu nie chcą być dziś Rusinami, tylko mianują się być Polakami. [...] Naśladując w tej mierze Rusinów - zwracał się Bogdanowicz do swych ziomków - ubliżalibyście sobie, swojej własnej godności, swojej narodowości i swojej przeszłości, jako należący do najstarożytniejszych narodów świata ${ }^{62}$.

W związku z tym projektował ,transsemigrację Ormian do kraju ojczystego, [...] na łono swej matki”, zwłaszcza do tej jej części, która znalazła się w granicach chrześcijańskiego Imperium Rosyjskiego. Ormianie polscy w nowej ojczyźnie powinni się przyczynić do jej okcydentalizacji i rozszerzenia katolicyzmu. Bogdanowicz miał bardzo pesymistyczne przewidywania co do losów sprawy polskiej w Galicji Wschodniej. Wobec tego deklarował, że w nowej ojczyźnie ormiańskiej znajdzie się miejsce także dla Polaków wschodniogalicyjskich, wygnanych z niej po triumfie Rusinów i Żydów ${ }^{63}$.

Trudno udzielić prostej odpowiedzi na pytanie o to, które z trzech stanowisk: anonimowego autora Głosu do ziomków..., księdza Isakowicza czy Roberta Rosco-Bogdanowicza, było najpopularniejsze wśród Ormian polskich w Galicji i na Bukowinie. Być może Bogdanowicz miał jakichś zwolenników, ale jego poglądy raczej szokowały, niż wzbudzały aprobatę innych Ormian. Brakuje realnych oznak ich solidarności z Armenią, jakichkolwiek prób ruszenia jej na pomoc, analogicznych do tych obserwowanych wśród Tatarów i Karaimów polskich w stosunku do ich ojczyzn etnicznych podczas I wojny światowej i tuż po niej. Ormianie galicyjscy nie posłuchali wezwań do czynów w duchu tego patriotyzmu, którego heroldem stał się Bogdanowicz. Prorosyjska orientacja Armenii okazała się tu dużym problemem. Zaangażowanie na jej rzecz byłoby wysoce kontrowersyjne $\mathrm{z}$ uwagi na antyrosyjskie stanowisko polityki polskiej, choć pamiętajmy, że przynajmniej jeden z głównych programów politycznych Polaków, głoszony przez Romana Dmowskiego, też stawiał w pewnym okresie na Rosję. Dmowski miał identyczne jak Robert Rosco-Bogdanowicz poglądy na kwestię zagrożenia niemieckiego i współpracy z Rosją.

Stanowisko centrystów w rodzaju księdza Isakowicza, broniących obrządku, a jednocześnie deklarujących polski patriotyzm, wydawało się najpopularniejsze. Z obserwacji zachowań społecznych wynika jednak, że tylko werbalnie odrzucano postulat likwidacji obrządku. W rzeczywistości - jak widzieliśmy - konwersja obrządkowa czyniła coraz to nowe spustoszenia. Patriotyzm polski w dobie I wojny

${ }^{61}$ R. Bogdanowicz, Kwestya Kościoła..., s. 39. Na temat zaangażowania politycznego Ormian w życie parlamentarne Galicji zob. K. Stopka, Ormianie w Galicji austriackiej, s. 91-92.

62 R. Bogdanowicz, Kwestya Kościoła..., s. 38-39.

63 Ibidem, s. 75-84; A.A. Zięba, Idea powrotu... 
światowej i po niej, w czasie walk o odbudowę państwa polskiego, był uważany przez grupę za postawę obowiązkową. Polskie zaangażowanie narastało wraz ze wzrostem polskich nadziei na odzyskanie niepodległości. Charakterystyczny przykład tego znajdujemy w księdze pamiątkowej prowadzonej w sanktuarium narodowym w Krakowie, na kopcu Kościuszki, usypanym na pamiątkę antyrosyjskiego powstania narodowego $\mathrm{z}$ roku 1794. Figuruje tam wpis dokonany przez przedstawiciela znanej i zamożnej rodziny ormiańskiej - Feliksa „de Kaminiczanul Magnaninusa" Theodorowicza. Rodowe przydomki, pieczołowicie zaznaczone przy nazwisku, świadczą o przywiązaniu do tradycji ormiańskich, ale treść wpisu jest bez wątpienia przejawem wręcz patetycznego polskiego uniesienia narodowego: „Wy, coście tu imiona wasze dziś złożyli / Pomnijcie, byście zawsze podobnymi byli / Temu, którego oto mogiłę zwiedzacie / Jeśli trochę polskiego uczucia chowacie" ${ }^{64}$. Renegocjacja tożsamości etnicznej podjęta w latach 1861-1884 potwierdziła więc wybór strategii dla całej wspólnoty. Wyborem tym okazała się asymilacja polska.

Pochodną kierunku asymilacji był stosunek Ormian galicyjskich do państwa austriackiego i innych grup etnicznych mieszkających w prowincji. Określając go, Ormianie nie tylko definiowali siebie, ale też społeczeństwo, z którym ich grupa się integrowała. Wobec Austrii zachowywano wyrachowaną lojalność. Stosunek Ormian do konfliktu polsko-ukraińskiego nie sprowadzał się tylko do jednej postawy. Wiemy o bliskiej koegzystencji ubogich rodzin ormiańskich z Pokucia z Rusinami, o ich ukrainizacji językowej, wspólnej emigracji zarobkowej do Kanady. Ziemianie ormiańscy wzorem swoich polskich sąsiadów patronowali życiu kościelnemu greckokatolickich poddanych. Wśród galicyjskich zwolenników ugody polsko-rusińskiej znajdujemy polityków ormiańskich ${ }^{65}$. W Galicji jako postawę reprezentatywną dla wszystkich Ormian względem Ukraińców uznano przekonania bogatych ziemian pochodzenia ormiańskiego, którzy przewodzili polskiemu stronnictwu „podolaków”. Byli to stanowczy przeciwnicy nowych tendencji politycznych Rusinów galicyjskich powstałych w opozycji do programów rusofilskich. Do wrogów ukraińskiego programu narodowego należał też Aleksander Krzeczunowicz, który już po upadku Austrii postulował stanowczą walkę Polaków z aspiracjami terytorialnymi Ukraińców i przyłączenie do Polski nie tylko Galicji Wschodniej, ale też Podola rosyjskiego ${ }^{66}$.

Wśród Ormian galicyjskich jednoznacznie negatywne emocje budzili natomiast Żydzi, ich dawni konkurenci w handlu, którzy w XIX wieku pojawili się jako pretendenci do dóbr ziemskich oraz jako syjoniści uznawani za zagrożenie polityczne dla sprawy polskiej. Robert Rosco-Bogdanowicz alarmował ziomków: ,[...] czy macie doczekiwać hańby, aby dzieci wasze stały się służalcami Żydów [...] i widzieć naszą ukochaną teraźniejszą ojczyznę przeistoczoną w północną Palestynę?"'67. Oczywiście „ziomkowie” z tą wizją pogodzić się nie chcieli. Ziemianki ormiańskie spod Rohatyna poświęciły się „wyrabianiu opinii w kierunku piętnowania sprzedawczyków [tj.

${ }^{64} 180$ lat Kopca Kościuszki, Kraków 2001, s. 68.

${ }_{65}$ K. Stopka, Ormianie w Galicji austriackiej, s. 107-108.

66 A. Krzeczunowicz, Przyszłość Słowian i kwestia ruska w Galicji i na Podolu, Kraków 1919;

W. Feldman, Stronnictwa i programy polityczne w Galicji 1846-1906, t. 1, Lwów 1907, s. 230.

${ }_{67}$ R. Bogdanowicz, Kwestya Kościoła..., s. 75-76. 
tych, którzy sprzedawali ziemię Żydom - przyp. K.S.], nie cofając się nawet w danych wypadkach przed ostrym bojkotem towarzyskim" ${ }^{98}$. Czasami trzeba było walczyć ze swoimi, na przykład Dawid Abrahamowicz był publicznie wytykany przez prasę za wydzierżawienie Żydom folwarków, którymi administrował jako opiekun sierot po Kornelu Krzeczunowiczu. Antyżydowską frustrację Ormian galicyjskich powiększał fakt, że ich wschodnią aparycję często brano za żydowską, z czego korzystało zresztą wielu neofitów, podając się za Ormian ${ }^{69}$.

Pod koniec wieku XIX stan stosunków narodowościowych uzmysłowił wszystkim segmentom społeczności ormiańskiej - ziemianom, inteligentom, rzemieślnikom i drobnej burżuazji, że sukces społeczny, jaki osiągnęli, zajmując pozycje elitarne w każdej z tych warstw społeczeństwa polskiego, okazał się niestabilny, gdyż status polskości w Galicji Wschodniej jest zagrożony przez roszczenia Ukraińców i Żydów. Opinie Bogdanowicza w tej kwestii były podzielane. Ale dotyczyło to tylko jego obaw co do losu inteligencji i ziemian pochodzenia ormiańskiego, gdyby polityka polska doznała tutaj klęski. Zamiast słuchać wezwań do powrotu na łono ojczyzny kaukaskiej i do walki z „,fanatycznymi wyznawcami Mahometa”, Ormianie galicyjscy woleli się jednak skupić pod sztandarami polskiej Narodowej Demokracji Romana Dmowskiego, by pod jej kierunkiem podjąć walkę o prymat z Ukraińcami i Żydami. To była główna przyczyna, dla której stali się zapleczem tej coraz bardziej popularnej w tym regionie ideologii politycznej. To, co Robert Bogdanowicz pisze o Rusinach i Żydach, wyprzedza nawet ewolucję polityczną Narodowej Demokracji. Można go nazwać protagonistą programu owego stronnictwa odnośnie do kwestii ukraińskiej i żydowskiej.

Natchnionym prorokiem wspomnianego kierunku politycznego, którego publiczne wystąpienia zyskiwały masowe poparcie dla Narodowej Demokracji, a polityczny temperament rodem z popularnego stereotypu Ormianina wprowadzał niezwykły dynamizm do jej działań politycznych, stał się w Galicji arcybiskup ormiański Józef Teodorowicz. To jego stanowcza postawa podczas pertraktacji nad reformą prawa wyborczego do Sejmu Krajowego, skutkująca zwiększeniem uprawnień dla Ukraińców, doprowadziła do upadku namiestnika Michała Bobrzyńskiego. Arcybiskup stał się w tym momencie siłą kierowniczą względem raczej pasywnych politycznie biskupów polskich obrządku łacińskiego. W czasie I wojny światowej wystąpił z kolei z rewolucyjnym projektem sprowadzenia do Galicji 20000 Ormian zagrożonych w Turcji, w intencji nie tylko ocalenia ich życia, ale również stworzenia solidnej dywersji demograficznej przeciw wchodniogalicyjskim rywalom Polaków.

W sprawie ormiańskiej najważniejszym dla Teodorowicza elementem więzi wspólnotowej był obrządek - „,szczytny dowód bogactwa i płodności ducha tego społeczeństwa, z którego serca wypłynął”. Nie chciał się jednak odwracać od społeczeństwa polskiego z powodu pamięci o Armenii. Uważał, że poznawanie ,języka i obyczaju, nawet i historii, i życia kulturalnego" narodu, ,z któregośmy przed wiekami wyszli”, nie jest sprzeczne z polskim patriotyzmem. Według niego „obrządek

68 „Strażnica Polska” R. IV, 1882, nr 1, s. 6.

69 List wstępny do G. ben Josua Hoeschel Schossburg, Brama pokuty, Paryż 1879. 
i pewna odrębność pochodzenia" nie przeszkadza obowiązkom ziemi, na której od wielu pokoleń rodzili się Ormianie polscy. Istnienie Ormian polskich uznawał za dobro całego społeczeństwa jako jego dwukierunkowe ulepszenie: dostrojenie uczuciowe Ormian i upraktycznienie charakteru polskiego. Arcybiskup był przekonany, że tożsamość Ormianina katolika stanowi zasadniczą wartość dla całego narodu ormiańskiego i szczególne zobowiązanie dla posiadaczy tej tożsamości. Ich zadaniem jest „rzucić płomień świetlisty dla tych, którzy zgubili drogę”, czyli pozostawali poza Kościołem katolickim ${ }^{70}$.

W pewnym sensie arcybiskup Teodorowicz dokonał syntezy wszystkich trzech stanowisk prezentowanych przez autorów omówionych tu publikacji. Odnowił więź ze społecznością ormiańską na świecie, jak chciał Rosco-Bogdanowicz. Jednocześnie jeszcze głębiej i na trwałe zaangażował swą wspólnotę w sprawę polską, jak tego pragnął anonimowy autor Głosu do ziomków... Dzięki wysiłkom i wrażliwości estetycznej Teodorowicza katedra ormiańska we Lwowie przestała przypominać „katakumbę" w ponurych barwach odmalowaną przez tegoż autora, bo arcybiskup tchnął nowego ducha w obrządek ormiański, zgodnie z marzeniami księdza Isakowicza ${ }^{71}$.

Na skutek tych procesów wykształciła się specyficzna tożsamość Ormian polskich, którą dobrze oddaje łacińska formuła gente Armeni, natione Poloni (rodu ormiańskiego, narodowości polskiej), adekwatna do znanej w Galicji grupy gente Ruteni, natione Poloni. Akcentując polski patriotyzm, w środowisku tym chętnie powtarza się do dziś slogan, że „Ormianin to podwójny Polak”"72.

\section{BIBLIOGRAFIA}

\section{I. Źródła}

\section{1. Źródła archiwalne}

Biblioteka Czartoryskich, sygn. 2298 I: Historia krótko zebrana o narodzie i królestwie ormiańskim.

\section{2. Źródła drukowane}

Bogdanowicz R., Kwestya Kościoła obrządku ormiańskiego i tegoż posłannictwa jakoteż Kwestya Armeńska na wschodzie w ich własnym kraju, Brzeżany 1884.

70 List pasterski X. Arcybiskupa Józefa Teodorowicza do duchowieństwa i wiernych obrządku orm. wydany 2 lutego 1902 r. w dzień konsekracji biskupiej i intronizacji, Lwów 1902. Omówienie i analiza u: A.A. Zięba, Czy można być ormiańskim patriotą i polskim biskupem katolickim jednocześnie? Arcybiskup Józef Teodorowicz jako Ormianin [w:] Ormiański pasterz Lwowa ..., s. 199-232.

${ }^{71}$ J. Wolańska, Katedra ormiańska we Lwowie w latach 1902-1938. Przemiany architektoniczne i dekoracja wnętrza, Warszawa 2010; Katedra ormiańska we Lwowie i jej twórcy, Kraków 2016.

72 Nie czuli się zatem mniejszością narodową, a nawet wspólnotą subetniczną - jak chce tego jeden z badaczy. Zob. G. Pełczyński, Ormianie w Polsce w XX wieku, Warszawa 1997. 
Catalogus universi cleri archi-dioecesis leopoliensis ritus armeni pro anno 1843, Leopoli 1843.

Catalogus universi cleri archi-dioecesis leopoliensis ritus armeni pro anno 1858, Leopoli 1858.

Głos do ziomków obrządku ormiańsko-katolickiego, Lwów 1861.

Isakowicz I., Odprawa autorowi broszury „,Głos do ziomków obrządku ormiańsko-katolickiego”, Wiedeń 1861.

List pasterski X. Arcybiskupa Józefa Teodorowicza do duchowieństwa i wiernych obrzadku orm. wydany 2 lutego 1902 r. w dzień konsekracji biskupiej i intronizacji, Lwów 1902.

Odpowiedź księdzu Isakowiczowi, Lwów 1861.

\section{Pamiętniki i wspomnienia}

Chłędowski K., Pamiętniki, t. 2: Wiedeń (1881-1901), do dr. przygot., wstęp i przyp.

A. Knot, Kraków 1951.

Jabłonowski L., Pamiętniki, oprac., wstęp i przyp. K. Lewicki, Kraków 1963.

Rosco-Bogdanowicz M., Wspomnienia, oprac. J. Gintel, t. 1-2, Kraków 1859.

\section{Prasa}

„Kraj” 1901.

„Przyjaciel Domowy” 1855-1856.

„Tygodnik Katolicki” 1861.

\section{Opracowania}

Barącz S., Pamiątki miasta Stanisławowa, Lwów 1858.

Barącz S., Pamiątki miasta Żółkwi, Lwów 1852.

Barącz S., Pamiętnik dziejów polskich z akt urzędowych lwowskich i rękopisów, Lwów 1855.

Barącz S., Rys dziejów ormiańskich, Tarnopol 1869.

Barącz S., Żywoty sławnych Ormian w Polsce, Lwów 1856.

Bołoz-Antoniewicz J. Ritter von, Die Armenier [w:] Die österreichisch-ungarische Monarchie in Wort und Bild, Bd. 19: Galizien, Wien 1898, s. 440-463.

Estreicher K., Bibliografia polska XIX wieku, t. 4, Kraków 1916, s. 517.

Feldman W., Stronnictwa i programy polityczne w Galicji 1846-1906, t. 1, Lwów 1907.

Katedra ormiańska we Lwowie i jej twórcy, Kraków 2016.

Korwin L., Ormiańskie rody szlacheckie w Polsce, Kraków 1934.

Krzeczunowicz A., Przyszłość Słowian i kwestia ruska w Galicji i na Podolu, Kraków 1919.

Kumor B., Obsada arcybiskupstwa ormiańskokatolickiego we Lwowie w latach niewoli narodowej (1772-1918), „Analecta Cracoviensia” 1994, t. 26, s. 371-385.

Lechicki Cz., Kościót ormiański w Polsce, Lwów 1928. 
Miławicki M., ,Świat ode mnie zawsze rzeczy nadzwyczajnych wymagat, a ponadto niestusznie”. O. Sadok Wincenty Baracz (1814-1892) w świetle źródet, „Lehahayer” 2013, nr 2, s. 153-197.

Pełczyński G., Ormianie w Polsce w XX wieku, Warszawa 1997.

Petrowicz G., La Chiesa Armena in Polonia e nei paesi limitrofi, parte 3: 1686-1954, Roma 1988.

Rok B., Ormianie w kościele rzymskokatolickim w XVIII wieku [w:] Rola mniejszości narodowych w kulturze i oświacie polskiej w latach 1700-1939, red. A. Bilewicz, S. Walasek, Wrocław 1998, s. 19-41.

Stopka K., Języki oswajane pismem. Alografia kipczacko-ormiańska i polsko-ormiańska w kulturze dawnej Polski, Kraków 2013.

Stopka K., Ormianie polscy czy ukraińscy? O sposobie pisania historii Ormian na ziemiach dzisiejszej Zachodniej Ukrainy, „Lehahayer” 2010, nr 1, s. 149-171.

Stopka K., Ormianie polscy - początki [w:] Ormianie, red. B. Machul-Telus, Warszawa 2014, s. 13-44.

Stopka K., Ormianie w Galicji austriackiej [w:] Ormiański pasterz Lwowa ksiadz arcybiskup Józef Teodorowicz na tle dziejów ormiańskich, red. W. Osadczy, M. Kalinowski, M. Jacov, Lublin-Lwów 2015, s. 73-112.

Stopka K., Ormianie w Polsce dawnej i dzisiejszej, Kraków 2000.

Stopka K., Ormiańskie sacrum i profanum, czyli o fundamencie kulturowym Ormian polskich [w:] Ormianie, red. B. Machul-Telus, Warszawa 2014, s. 77-98.

Stopka K., Stefanowicz Samuel Cyryl [w:] Polski stownik biograficzny, t. 43, WarszawaKraków 2005, s. 211-216.

Wasyl F., Ormianie w przedautonomicznej Galicji. Studium demograficzno-historyczne, Kraków 2015.

Wolańska J., Katedra ormiańska we Lwowie w latach 1902-1938. Przemiany architektoniczne i dekoracja wnętrza, Warszawa 2010.

[Zachariasiewicz F.K.] X.Z., Wiadomość o Ormianach w Polszcze, Lwów 1842.

Zaleski T., Biskup ormiański Izaak Mikołaj Isakowicz „,Złotousty”, Kraków 2001.

Zaleski T., Słownik biograficzny duchownych ormiańskich w Polsce, Kraków 2001.

Zięba A.A., Czy można być ormiańskim patriota i polskim biskupem katolickim jednocześnie? Arcybiskup Józef Teodorowicz jako Ormianin [w:] Ormiański pasterz Lwowa ksiadz arcybiskup Józef Teodorowicz na tle dziejów ormiańskich, red. W. Osadczy, M. Kalinowski, M. Jacov, Lublin-Lwów 2015, s. 199-232.

Zięba A.A., Idea powrotu Ormian z rozproszenia do narodowego państwa $w$ historycznej ojczyźnie w świetle memoriału Roberta Bogdanowicza z 1884 roku (w druku).

Zięba A.A., Patriotyzmy polskich Ormian [w:] Ormianie, red. B. Machul-Telus, Warszawa 2014 , s. $45-56$. 